\section{ENTRAPMENT OF FREE CELLS WITHIN ELECTROSPUN NANOFIBERS: MINI REVIEW ON PARAMETERS INFLUENCING NANOFIBERS CHARACTERISTICS AND CELLS VIABILITY}

\author{
Aiman Farhana Azaddin, Roshanida A. Rahman*, Mazura Jusoh, \\ Juhana Jaafar, Norzita Ngadi, Nor Hasmaliana Abdul Manas \\ School of Chemical and Energy Engineering, Faculty of Engineering, \\ Universiti Teknologi Malaysia, 81310 UTM Johor Bahru, Johor, Malaysia
}

Article history

Received

25 April 2020

Received in revised form

14 October 2020

Accepted

19 October 2020

Published online

27 October 2020

*Corresponding author

r-anida@utm.my

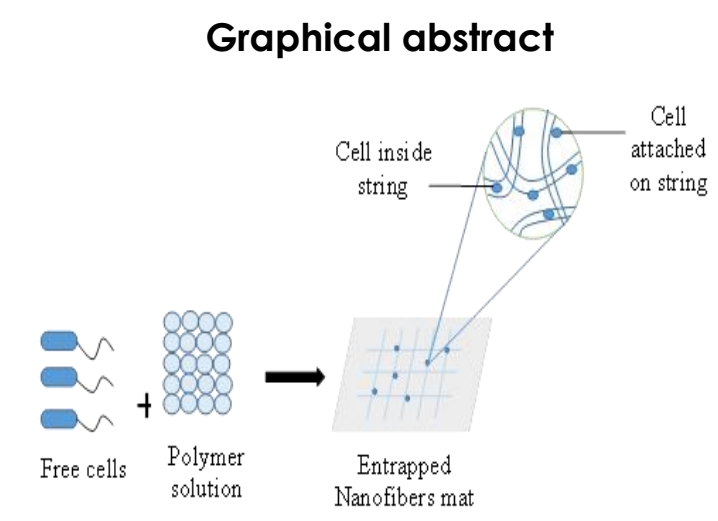

Entrapment mechanism in electrospun nanofibers mat

\begin{abstract}
Nanotechnology is a growing technology that has been recognized as vital and scientific with bioprocess development especially in dealing with usage of free cells. Limitations such as low bioavailability, storage instability and low substrate inhibition bound the application of free cells in various field thus leading researchers into focusing more on free cells immobilization system. With the increasing knowledge in nanomaterials fabrication techniques, the immobilization of free cells through entrapment approach in highly porous and the high surface area of nanofibers is becoming an interesting subject to be highlighted. The production of free cells entrapped in nanofibers via electrospinning in terms of quality and quantity is highly affected by the electrospinning operating parameters including solution formulation, ambient conditions, operating conditions of electrospinning machine and types of materials used. Hence, this review paper will provide an overview of the operating conditions involved in electrospinning of cells through entrapment process which affect the characteristics of the electrospun nanofibers produced and the viability or growth of cells when entrapped in the electrospun nanofibers mats.
\end{abstract}

Keywords: Entrapment, immobilization, electrospinning, nanofibers, viability

\begin{abstract}
Abstrak
Nanoteknologi adalah sebuah teknologi yang berkembang yang telah diakui penting dan saintifik dengan perkembangan bioproses terutama dalam menangani penggunaan sel bebas. Keterbatasan seperti rendah ketersediaan bio, ketidakstabilan penyimpanan dan rendah perencatan substrat mengikat penerapan sel bebas dalam pelbagai bidang sehingga menyebabkan para penyelidik lebih fokus pada sistem imobilisasi sel bebas. Dengan meningkatnya pengetahuan dalam teknik fabrikasi bahan nano, imobilisasi sel bebas melalui kaedah pemerangkapan di dalam fiber nano berpori tinggi dan keluasan yang tinggi menjadi subjek yang menarik untuk diketengahkan. Pengeluaran sel bebas yang terperangkap dalam serat fiber nano melalui proses elektrospin dari segi kualiti dan kuantiti sangat dipengaruhi oleh parameter semasa pengoperasian elektrospin termasuk formulasi larutan, keadaan ambien, keadaan operasi mesin elektrospin dan jenis bahan yang digunakan. Oleh itu, kajian ini akan memberikan gambaran keseluruhan keadaan operasi yang terlibat di dalam elektrospin sel
\end{abstract}


melalui kaedah pemerangkapan ke atas ciri-ciri bahan fiber nano yang dihasilkan serta kebolehidupan atau pertumbuhan sel ketika terperangkap dalam fiber nano tersebut.

Kata kunci: pemerangkapan, imobilisasi, elektrospin, bahan nano, kebolehidupan

(C) 2020 Penerbit UTM Press. All rights reserved

\subsection{INTRODUCTION}

Cells are defined as living microorganisms which refers to microscopic organisms such as bacteria, viruses or fungi. The ability of cells in releasing extracellular enzymes, organic acid, therapeutic proteins and biomolecules makes them vitally important in modification and maintenance of our environment [1]. In recent years, there is a surging interest in bioprocess development due to increasing demand in using cells for their potential applications in the field of pharmaceutical, medical, agriculture and environmental protection [2]. For example, cells have been used widely in wastewater treatment due to their great potentials and ability to treat environmental contaminants as they have wide range of sorption sites. Not only that, increasing demand in applying bacterial viruses and fungal cells as an alternative to bacterial antibiotics and industrial application have been prominent too [3]. However, the low substrate inhibition, low solubility in substrate and instability of using cells in free form limit the cells activity. These limitations require a competent delivery approach and development of means for effective entrapment that can ensure delivery of these cells to the desired destination and enhance its bioavailability [2].

Entrapment has been regarded as an effective method to entrap cells within a carrier for the purpose of protecting the cells to a targeted site from any environmental shear stress $\mathrm{lpH}$ and temperature) and improves the stability of cells [4]. Entrapment of cells is one of the immobilization methods which refer to the localization of cells within the lattice of a polymer carrier. Besides, cell entrapment can retain higher biomass concentration and cell activity during applications. Entrapped cells are very useful in biotechnological applications including bioremediation [5,6], particle biofilm reactors [7-9], phage therapy [10] and regenerative medicine transplant cells [11-14]. In the literature, various techniques have been reported for cells entrapment include inclusion in gels, fibers and microcapsules, spray drying [15], freeze drying [16], emulsification [17], supercritical fluid [18], and nanoprecipitation [2]. However, certain techniques such as entrapment via spray drying and solvent casting are not compatible for entrapment of cells, for example which consumes high working temperature and organic agents during the process which may lead to degradation and destruction of sensitive entrapped cells. Hence, the stability of cells during entrapment will be affected [19]. In most of these attempts, cells are usually entrapped in polymeric materials which have important shortcomings such as low viability of cells, insufficient diffusion through material and poor thermal and mechanical stability [20-23]. Therefore, it is important to find the appropriate techniques to entrap the cells and biocompatible environment for the cells growth that does not involve severe conditions once they have been entrapped in a carrier. Due to this condition, electrospinning technology has been identified as a promising initiative in entrapment of cells due to the absence of temperature required in this process which can secure the stability of the cells. In addition, the properties of electrospun nanofibers such as high surface area with nano-level diameter, light-weight, nano-porous structure, high flexibility and reusability are desirable for the entrapment of cells which can enable the nanofibers to act as a carrier [24].

The growing literature on electrospinning of cells has helped this technology to pave its way towards advancements in the areas of biomedical, agriculture and electronic appliances. The similarity of nanofibers to natural biological tissues which can be organized into porous fibers architecture makes them useful in many applications [25]. The ability to fabricate nanofibers as a carrier for cell entrapment from various types of material ranging from natural and synthetic polymers to composites, has encouraged researchers to conduct more studies on this technology. Research proved that cells can be successfully entrapped in a natural nanofibers form such as alginate, carrageenan and chitosan [26] or synthetic such as polyvinyl pyrrolidone (PVP) and polyvinyl alcohol (PVA) [24] which provides greater biocompatibility and simple gelation with the entrapped cells compared to natural polymers. Some examples include polyethylene oxide (PEO), PVA and PVP which have been frequently used to entrap cells because they are economically friendly, nontoxic, have low mass transfer resistance and are physically stable due to its lattice structure which has dense porosity and specific pore volume [4]. 
When considering for an entrapment system, electrospun nanofibers have been proven to be the promising platform as they have succeeded in the entrapment of nano-particles, enzymes and whole cells [27-32]. The overview above shows the possibility of combining nanofiber and bioprocess technology. However, there is very few review papers that discuss the electrospinning parameters affecting the cells entrapment process in nanofiber. Thus, the aim of this paper is to provide a review of the recent studies on the impact of electrospinning parameters toward the quality and quantity of the electrospun cell entrapped in nanofiber. This includes the fundamental knowledge on the entrapment mechanism between cells and polymer type relationship. It will also help in understanding electrospinning and the selection of critical operating parameters which affect the cells. The study of effect on the growth and cells viability once entrapped within the nanofibers is also presented in this review paper.

\subsection{ELECTROSPINNING PROCESS}

Electrospinning is a fabrication method for threedimensional nanomaterial that allows the control of pore size and diameter of fiber which in turn provides better control compared to cell infiltration [33]. Electrospinning refers to the technology of fiber formation which is based on the electrostatic attraction of charges. The instrument comprises of three main parts; high voltage supply, the syringe and the collector as shown in Figure 1 [34]. The polymer solution in the syringe has its own surface tension due to the moving electric charges via the metallic needle. This phenomenon causes instability within the polymer solution due to induction of charges on the polymer droplet. In the meantime, reciprocal repulsion of charges produces a force that opposes the surface tension which eventually charge out the polymer solution by applying high voltage of power supply. To collect the ejected fibers from the syringe, the collector is designed in opposite charges. As the solution emerges from the syringe by the help of voltage supply, it will produce a coneshaped surface called 'Taylor- cone' [35]. It can be extended by ensuring there is high charge density on the collector. Basically, electrospinning process is conducted at room temperature with atmospheric condition.

Electrospinning instrument can be classified into many classes, and the major classes are the vertical and horizontal in setup. In general, horizontal type instrument refers to the charge force received by applying the voltage supply and opposite attractive charges on the collector. Meanwhile, vertical type instument is when two forces are used to draw the fibers in which the common one is collector, and the other one is the gravitational pull [34]. Rodoplu (2012) investigated the effect of using both horizontal and vertical type of electrospinning on the operating parameters. The vertical system involves gravitational force while horizontal does not which resulted in difference in shape of the polymer droplet and Taylor cone [36]. Electrospinning process has numerous advantages over other fiber production methods such as: 1) provides nanofibers with malleability and reusability over time; 2) more durable compared to other nanoparticle or carbon nanotubes; 3) easy incorporation of microbiological cells into nanofibers; 4) high surface area and tunable porosity to varieties of sizes and diameters which makes it easy to control the nanofiber composition to the desired results especially for the entrapment of microbiological cells. Due to these structural forms of nanofibers, stability and bioavailability of entrapped cells will be enhanced [2]. Hence, it is crucial to have a clear understanding on the entrapment mechanism during electrospinning process in order to optimize the production of nanofibers incorporated with the microorganism cells.

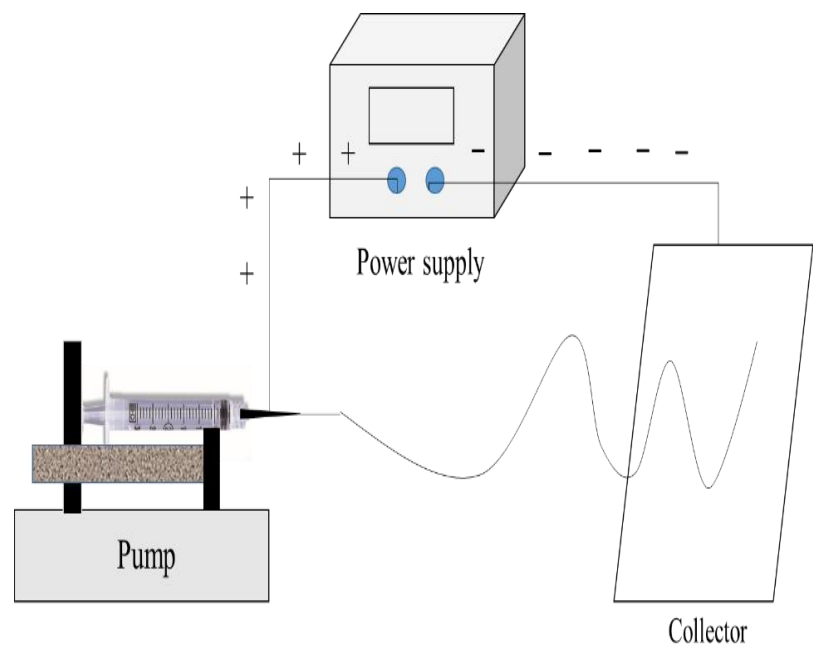

Figure 1 Electrospinning machine setup

\subsection{ENTRAPMENT PRINCIPLE OF CELLS IN ELECTROSPUN NANOFIBERS}

When using nanofibers as a carrier, cells must first be immobilized in the polymer structure for the release control mechanism to operate. Entrapment of cells in a carrier can be formed either by chemical or physical means during the immobilization process. In order to achieve it, the structure of the carrier and conditions for the cell growth during entrapment must be compatible with the requirement of cells. A carriers are defined as a phase which act as a support either in solid, liquid or gelation form for cell entrapment which are different from substrate and the products [37]. Compared to other types of carrier such as foam and gel films, entrapment on a solid support especially in nanofibers has gained great attention because it allows easy separation and 
reuse of the products [38]. In electrospinning process, the entrapment of cells in nanofibers can be achieved by direct electrospinning of cells with other components such as polymers. Commonly, water soluble polymers are used to entrap cells due to their properties such as good fiber forming characteristic, non-toxic, able to retain high bioavailability of the cells and will undergo solvent evaporation during the electrospinning process which can help in extending the shelf life of cells $[39,40]$. On top of that, these polymers show relatively high degradation in aqueous environment which is desirable in applications that need quick release of cells [21]. Therefore, in most cases, water soluble polymers have been used to dissolve the cells so that they can form homogenous solution with the cells. This condition can reduce the surface tension during the electrospinning which is necessary to produce beadfree nanofibers.

During the electrospinning, cells are physically entrapped inside the porous nanofibers either incorporated along the fiber length because of the cell size is larger than the nanofibers diameter or inside the fiber forming a structure called spores-ona-string type due to the smaller size of the cells compared to the nanofibers diameter [22]. Bonds involved in stabilizing the cells onto the polymer chains during electrospinning may be covalent or non-covalent depending on the natural properties of substrate or adsorbate. Commonly, water soluble polymers such as PVA and PVP are used due to their dissimilar structure to cells. During electrospinning, the nanofibers strings overlap with each other in a completely random manner which leads to the open structure ideal to release the functional cells or as membrane for filtration as shown in Figure 2. The pore and size of the nanofibers string can be adjusted by manipulating the concentration of polymer used to prevent the loss of cells.

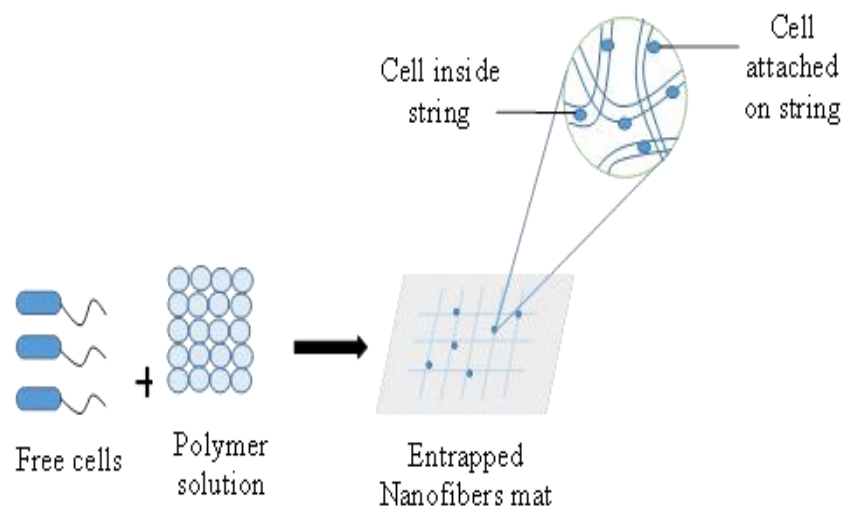

Figure 2 Entrapment mechanism in electrospun nanofibers mat

The electrospinning process begins when cells are distributed into the polymer solution. Due to the moving electrical charges in the solution and external voltage supply, the cells are sucked into the jet by sink-like flow of the Taylor-cone formed at the tip of the syringe $[19,41]$. The electrical charges are basically distributed only on the free surface of the jet which makes the cells not affected electrically. However, the cells might be affected by the hydrodynamic stresses in the jet which is primarily viscous stress in the order of $10^{5} \mathrm{Nm}^{-2}$ if the solution viscosity is not controlled [42]. On top of that, it is important to know that cells cannot withstand stress in the order of $10^{3} \mathrm{Nm}^{-2}$ [43]. Abrupt changes in the osmotic environment can also happen due to enormous evaporation during the electrospinning process.

\subsection{EFFECTS OF ELECTROSPINNING PARAMETERS ON NANOFIBERS QUALITY}

Electrospinning process is highly affected and governed by many types of parameters which are solution, processing and ambient parameters. However, the significant operating parameters which give major effects to the electrospinning of cells are categorized under the solution and processing parameter. These parameters will determine and control the morphology of the electrospun nanofibers when entrapped with cells. Each of these parameters must undergo proper manipulation to get electrospun nanofibers with desired diameter in order to hold and support the cells firmly for any application [44].

\subsection{Needle Tip to Collector Distance}

The distance between the tip and the collector is one of the factors that can affect the fiber diameter and its morphology. It provides sufficient opportunity for the solvents to get evaporated. Numerous research groups found that optimum distance is required to allow the solvent used to fabricate the nanofibers to have sufficient time to evaporate before reaching the collector, otherwise with distances that are too close or too far, beaded fiber will be seen [45]. Pham (2006) has proved that when minimize the distances between the tip and the collector, a small diameter of nanofibers is yielded [46]. Thenmozi et al. (2017) found that with lesser distance, thicker or beaded formation might occur whereas more distance will result in discontinuous fibers.

Most studies demonstrated that the common distance used between the tip of the syringe needle and the collector during electrospinning of cells is in the range of $10 \mathrm{~cm}$ to $15 \mathrm{~cm}$ as shown in Table 1 . It has been found that in electrospinning of cells, distilled water is commonly used to dissolve the polymer prior to spinning to prevent any destruction of cells from using organic agents [22]. Sufficient time is needed to dry the solvent before reaching the collector since the boiling point of distilled water is 
quite high at $100^{\circ} \mathrm{C}$. Salalha et al., (2006) succeeded in electrospinning bacteria (Escherichia coli, Staphylococcus albus) and viruses (T7, T4, $\lambda$ ) in aqueous poly (vinyl alcohol) (PVA) nanofibers by setting the distance between the electrode tip and the edge of the disc at $12 \mathrm{~cm}$. The resulting nanofibers exhibited excellent property for lyophilization process in preserving the cells for therapeutic and biological treatment. The viability study shows that cells remained viable up to three months at both temperature of -20 and $-55^{\circ} \mathrm{C}$ with 100 percent of viability for S. albus. Meanwhile, Spasova et al. (2011) demonstrated electrospinning of Trichoderma virides spores in nanofibers fabricated from composites polymer of chitosan/PEO with distance of $12 \mathrm{~cm}$ and resulted in varied diametersof nanofibers. Despite of various diameters of nanofibers obtained, the fungal spores remained viable and intact with the nanofibers when inoculated on PDA agar.

\subsection{Applied Voltage}

Generally, it is a known fact that spherical droplet will deform into Taylor cone at critical value and form ultrafine nanofibers due to the flow of the current supplied by the high voltage power to the polymer solution through the metallic syringe needle. This fact has also been approved experimentally where the shape of Taylor cone changes with varied voltage power supply [47]. To electrospin a good nanofiber, there is a need in knowing the critical voltage value as every critical value differs from polymer to polymer. Deizel et al. implied that the change in the spinning current is attributed to the change in the instability mode [48]. In electrospinning of cells, applying a voltage of more than $30 \mathrm{kV}$ is not favorable as it may destruct the cells during the spinning. Researchers reported that the common voltage supply used in electrospinning of cells lies in the range of $13 \mathrm{kV}$ to 30 $\mathrm{kV}[49]$.

An increase in the applied voltage beyond the critical value will cause more polymer to be injected and this will contribute to larger fiber diameter and thicker nanofiber [50]. This condition is not favorable for high efficiency of entrapment as the porosity of nanofibers will decrease with increasing fiber diameter. Lee et al. (2003) have succeeded in preserving the cells in electrospinning suspension of virus M13 with PVP in the range of $20 \mathrm{kV}$ to $30 \mathrm{kV}$ [51]. The resulted nanofibers diameter showed a relatively broad distribution ranging from micrometers to tens of nanometers. Not only that, there is a greater probability of beads formation when high voltage is applied. The same result was observed on the behavior of voltage applied and diameter of fiber by Larrondo and Menley (1981) [52]. With the greater applied voltage, Baumgarten (1971) observed a twofold increase in fiber length but only small changes in fiber diamater.

An investigation has been done to observe the voltage dependence on the fiber diameter using polystyrene (PS) [53]. As voltage increased from $5 \mathrm{kV}$ to $12 \mathrm{kV}$, the PS fiber size decreased from $20 \mu \mathrm{m}$ to 10 $\mu \mathrm{m}$ while there was no significant change observed in the pore distribution. However, there were also some cases in which higher voltage supplied resulted in greater stretching of the solution in the syringe due to the greater columbic forces in the jet as well as stronger electric field and these conditions will reduce the fiber diameter. Generally, the theory of increasing the applied voltage will increase the deposition rate due to higher mass flow from the needle tip has been accepted.

\subsection{Solution Flow Rate}

The flow rate of polymer solution ejected from the syringe is one of the crucial and significant factors as it can influence the jet velocity and the solution transfer rate. It has been observed that by increasing the solution flow rate, the pore and fiber diameter will increase as well [25]. Furthermore, changing the flow rate of the polymer solution may change the morphological structure of nanofibers if the nanofibers had pronounced beaded morphologies. Studies have been conducted in proving the relationship between the solution polymer flow rate with fiber morphology and size which resulted in beaded fibers at high flow rates due to insufficient proper drying time before reaching the collector [53]. Hence, uniform beadless electrospun nanofibers could be prepared by setting the system at critical flow rate.

Generally, the critical flow rate value varies with the polymer solution. The lowest flow rate used by researchers to electrospin cells was $0.2 \mathrm{ml} / \mathrm{h}$ which produced uniform thickness of nanofibers without formation of beads [21]. This condition proved that entrapped cells still remained viable for three months at the temperature of $-20{ }^{\circ} \mathrm{C}$ and $-55{ }^{\circ} \mathrm{C}$. However when the solution flow rate increased to $0.7 \mathrm{ml} / \mathrm{h}$, Spasova et al. (2017) proved that beaded nanofibers were produced. Luu et al. (2003) succeeded in releasing the DNA from $E$. coli electrospun within nanofibers for therapeutic application in gene delivery system by setting the flow rate at $1.2 \mathrm{ml} / \mathrm{h}$ [54]. This is because increases and decreases in the solution flow rate affect the formation of nanofibers diameter. To maintain the nanofibers morphology, optimum flow rate is needed to balance the ejected polymer solution and solution that is replaced during jet formation [55]. It is also important for the formation of stable jet cone to avoid receded jet which is referred to as unstable jets. In addition, besides the fiber formation at an elevated flow rate, defects such as unspun droplets and ribbon-like defects can be avoided. Huang et al. (2001a) observed that even small changes of flow rates would produce high impact and significant changes in the fiber morphology where bead formation become increasingly noticeable below $100 \mathrm{\mu lmin}^{-1}$, bead formation became increasingly noticeable while at flow rates above this value, limited volatility will hinder 
the sufficient fiber from drying under conditions of ambient temperature and pressure [56].

\subsection{Polymer Concentration}

In electrospinning process, optimum concentration of polymer solution is required. At low concentration of polymer solution, nanofibers with beads are produced and by increasing the concentration the beads shape to change from spherical to spindle-like and finally uniform fibers due to higher viscosity resistance [26]. Meanwhile, low concentration of polymer solution forms droplets due to the influence of surface tension. A number of studies have been documented as the literature on the difficulties in electrospinning polymers such as PEO, PAN and PDLA at certain concentration levels. At higher concentration level, PEO/water system have shown a bimodal distribution in fiber diameter. On top of that, the choice of polymer concentration depends on the application of nanofibers. Most studies especially involving bioprocess will vary the concentration of substances in order to observe the effect of concentration on the electrospinning process. To entrap cells in the electrospun nanofibers, researchers hve used polymer concentration between three percent $w / w$ to 35 percent $w / w$ as shown in Table 1. Spasova et al. (2010) succeeded in electrospinning $T$. viride spores by varying the polymer concentration of PEO at three percent $\mathrm{w} / \mathrm{W}$ and four percent $\mathrm{w} / \mathrm{w}$ to observe the effect of concentration on the nanofibers morphological. It was found that at three percent $\mathrm{w} / \mathrm{w}$ of polymer concentration, the nanofibers produced spindle-like defects along the fibers length. Meanwhile, the largest mean nanofibers diameter was obtained with spores-on-a-string type structure at four percent w/w of polymer concentration.

The effect of polymer concentration on nanofibers morphology was also reported by Lee et al. in electrospinning M13 virus suspension with PVP nanofibers [57]. The ratio between PVA solution and M13 suspensions was varied at 1:1, 1:2, 1:3 and 1:4 to observe the behavior of the nanofibers formed. Due to low viscosity and high surface tension, droplets of virus blended suspension were deposited on the nanofibers. Meanwhile, sporadic structure of nanofibers can be observed at ratio 1:3 which normally occurred due to low concentration of solution. A continuous nanofiber with uniform thickness was produced with ratio 1:4 which achieved the optimum concentration. The relationship between the average fiber diameter and the solution concentration was proven by the power law relationship and the variation of morphological fiber diameter was attributed to the delayed drying and stress relaxation behavior at low concentration [26]. Viscosity and surface tension of solution also play crucial factors in determining the range of concentrations and the limiting boundaries for the formation of electrospun nanofibers. Thus, there must be an optimum solution concentration as low concentration will induces the formation of beads. While at high concentration, the formation of continuous fibers is prohibited due to the inability to maintain the flow of the polymer solution ejected from the tip of the needle thus resulting in larger diameter of fibers.

\subsection{Polymer Molecular Weight}

Polymer molecular weight is one of the significant factors that affect the characteristics of nanofibers. The same polymer of different molecular weight will produce different nanofibers diameter. Molecular weight also has significant effect on rheological and electrical properties such as viscosity, surface tension, conductivity and dielectric strength which then affect the morphology of the nanofibers [58]. It has also been observed that low molecular weight polymer solution tends to form beads fibers and high molecular weight produces larger average diameter. Molecular weight represents the entanglement of polymer chain in a solution which is attributed to solution viscosity.

This entanglement plays an important role in the process of electrospinning. For example, even at low concentration of polymer, HM-PLLA (high molecular weight poly-L-lactic acid) can maintain sufficient number of entanglements of the polymer chains which ensures the level of solution viscosity in order to produce uniform jet during electrospinning and prevent the effect of surface tension which leads to bead formation [59]. This can be proved by the fact that beads were first observed from the LM-PLLA (low molecular weight poly-L-lactic acid) starting at minimum concentration of nine wt\% and concentration of $4.5 \mathrm{wt} \%$, HM-PLLA can produce beads free uniform fiber. Studies have been conducted to investigate the effect of polymer molecular weight when synthesizing PMMA by varying them from 12.47 to $365.7 \mathrm{kDa}$ and they found that as the molecular

In entrapment of cells through electrospinning, various molecular weights have been used depending on the type of polymer. It was found that in nanofibers, all the microorganism cells remained completely viable when using polyvinyl alcohol (PVA) at molecular weight of $10^{5} \mathrm{~g} \mathrm{~mol}^{-1}$. The electrospun nanofibers formed had a diameter ranging between 250 and $400 \mathrm{~nm}$ with uniform thickness along the nanofibers without any formation of beads [43]. Meanwhile, Vajdai et al. demonstrated electrospinning by using similar type of polymer which was PVA at different molecular weight $(31,000$ $\mathrm{g} / \mathrm{mol})$. S. maltophilia cells were suspended in the PVA solution and via electrospinning, these cells were entrapped within the nanofibers. The resulted electrospun nanofibers showed that the supramolecular structure of the polymeric chain was significantly changed due to swelling ability of PVA itself. Meanwhile, Lee et al. (2004) fabricated electrospun nanofibers by blending different ratios of suspensions between M13 virus suspensions in TBS and 
highly water soluble polymer which was PVP with molecular weight of $1,300,000 \mathrm{~g} / \mathrm{mol}$ [61]. Due to low viscosity and high surface tension of the aqueous suspension, the lowest ratios of suspension formed droplets of cells along the nanofibers.

\subsection{CONCLUSION}

Electrospinning has been proven as a flexible and powerful tool in cells entrapment compared to other methods which can cause severe conditions to the cells. This facile process produced nanofibers mats that can support cell entrapment by providing chemical and physical stability, biocompatibility structure of carrier and distribution of cells. By virtue of this advancement, the entrapment of cells in the electrospun nanofiber has high potential in achieving targeted delivery and sustained release. The resulting viability of cells shows that proper manipulation of parameters and operating conditions are crucial in producing good nanofibers and accordingly to their function. Recently, entrapment of different types of cells including bacteria and viruses through electrospinning process have been displayed as well as their potential applications. However, the fabrication of electrospun nanofibers entrapped with fungi is still at the lowest stage of development. Hence, advanced research is needed in the scope of fungi entrapment by electrospinning process for various applications.

\section{Acknowledgement}

This research is fully supported by FRGS grant, R.J130000.7851.5F210. The authors fully acknowledged Ministry of Higher Education (MOHE) and Universiti Teknologi Malaysia for the approved fund which makes this important research viable and effective.

\section{References}

[1] Ang, H. Y., S. Alexander Irvine, R. Avrahami, U. Sarig and T. Bronshtein. 2014. Characterization of a Bioactive Fiber Scaffold with Entrapped HUVECs in Coaxial Electrospun Core-shell Fiber. Biomatter. 4(1): 1-7

DOI: https://doi.org/10.4161/biom.28238.

[2] Wen, P., M. H. Zong, R. J. Linhardt, K. Feng and H. Wu. 2017. Electrospinning: A Novel Nano-encapsulation Approach for Bioactive Compunds. Trends in Food Science \& Technology. 70: 56-68 DOI: https://doi.org/10.1016/j.tifs.2017.10.009.

[3] Barrow, P. A., and S. James. 1997. Bacteriophage Therapy and Prophylaxis: Rediscovery and Renewed Assessment of Potential. Trends in Microbiology. 5(7): 268-271 DOI: https://doi.org/10.1016/S0966-842X(97)01054-8.

[4] Le, T. T. A., J. McEvoy and E. Khan. 2015. The Effect of Single-walled Carbon Nanotubes on Escheria Coli: Multiple Indicators of Viability. Journal of Nanoparticle Research volume. 17(32): 1-9 DOI: https://doi.org/10.1007/s11051-014-2827-y.
[5] Nicolella, C., M. C. Van Loosdrecht and J. J. Heijnen. 2000 Wastewater Treatment with Particulate Biofilm Reactors. Journal of Biotechnology. 80(1): 1-33 DOI: https://doi.org/10.1016/s0168-1656(00)00229-7.

[6] Crespo, J. G., S. Velizarov and M. A. Reis. 2004. Membrane Bioreactors for the Removal of Anionic Micropollutants from Drinking Water. Current Opinion in Biotechnology. 15(5): 463-468

DOI: https://doi.org/10.1016/j.copbio.2004.07.001.

[7] Nicolella, C., M. C. Van Loosdrecht and J. J. Heijnen. 2000. Particle-based Biofilm Reactor Technology. Trends in Biotechnology. 18(7): 312-320.

DOI: https://doi.org//10.1016/s0167-7799(00)01461-x.

[8] Rosche, B., X.Z. Li, B. Haver, A. Schmid, and K. Buehler. 2009. Microbial Biofilms: A Concept for Industrial Catalysis? Trends in Biotechnology. 27(11): 636-643.

DOI: https://doi.org/10.1016/j.tibtech.2009.08.001.

[9] Martin, H. 2005. Ordered Mesoporous Materials for Bioadsorption and Biocatalysis. Chem. Mater. 17(18): 45774593.

DOI: https://doi.org/10.1021/cm0485658.

[10] Salalha, W., J Kuhn, Y Dror and E. Zussman. 2006. Encapsulation of Bacteria and Viruses in Electrospun Nanofibers. Nanotechnology. 17(18): 4675-4681. DOI: https://doi.org/10.1088/0957-4484/17/18/025.

[11] Lim, G. J., S. Zare, M. Van Dyke, A. Atala. 2010. Cell Microencapsulation. Therapeutic Applications of Cell Microencapsulation. 670: 126-136. DOI: https://doi.org/10.1007/978-1-4419-5786-3_11.

[12] Murua, A., A. Portero, G. Orive, R. M. Hernandez, M. de Castro and J. L. Pedraz. 2008. Cell Microencapsulation Technology: Towards Clinical Application. Journal of Controlled Release. 132(2): 76-83.

DOl: https://doi.org/10.1016/j.jconrel.2008.08.010.

[13] Nicodemus, G. D. and S. J. Bryant. 2008. Cell Encapsulation in Biodegradable Hydrogels for Tissue Engineering Applications. Tissue Engineering Part B: Reviews. 14(2): 149-165. DOI: https://doi.org/10.1089/ten.teb.2007.0332.

[14] Uludag, H., P. De Vos and P. A. Tresco. 2000. Technology of Mammalian Cell Encapsulation. Advanced Drug Delivery Reviews. 42(1-2):29-64. DOI: https://doi.org/10.1016/s0169-409x(00)00053-3.

[15] Nedovic, V., A. Kalusevic, V. Manojlovic, S. Levic and B. Bugarski. 2011. An Overview of Encapsulation Technologies for Food Applications. Procedia Food Science. 1: 1806-1815 DOI: https://doi.org/10.1016/j.profoo.2011.09.265.

[16] Ray, S., U. Raychaudhuri and R. Chakraborty. 2016. An Overview of Encapsulation of Active Compounds Used in Food Products by Drying Technology. Food Bioscience. 13: 76-83.

DOI: https://doi.org/10.1016/j.fbio.2015.12.009.

[17] Sanguansri, P., and M.A. Augustin. 2006. Nanoscale Materials Development - A Food Industry Perspective. Trends in Food Science \& Technology. 17(10): 547-556. DOI: https://doi.org/10.1016/j.tifs.2006.04.010.

[18] Gouin, S. 2004. Microencapsulation: Industrial Appraisal of Existing Technologies and Trends. Trends in Food Science \& Technology. 15(7-8): 330-347. DOI: https://doi.org/10.1016/j.tifs.2003.10.005.

[19] Zussman, E. 2010. Encapsulation of Cells within Electrospun Fibers. Polymers Advanced Technologies. 22(3): 366-371. DOI: https://doi.org/10.1002/pat.1812.

[20] Meunier, C. F., P. Dandoy and S. Bao-Lian. 2010. Encapsulation of Cells within Silica Matrixes: Towards a New Advance in the Conception of Living Hybrid Materials. Journal of Colloid and Interface Science. 342(2): 211-214.

DOI: https://doi.org/10.1016/j.jcis.2009.10.050.

[21] Perez, C. Z. and C. A. Nussinovitch. 2004. Unexpected Distribution of Immobilized Microorganisms within Alginate Beads. Biotechnology and Bioengineering. 88(5):671-674. DOI: https://doi .org/10.1002/bit.20284. 
[22] Kourkoutas, Y., A. Bekatorou, I.M. Banat, R. Marchant and A. A. Koutinas. 2004. Immobilization Technologies and Support Materials Suitable Inalcohol Beverages Production: A Review. Food Microbiology. 21: 377-397 DOI: https://doi.org/10.1016/j.fm.2003.10.005

[23] Loscertales, I. G., A. Barrero, I. Guerrero, R. Cortijo, M. Marquez, A. M. Ganan-Calvo. 2002. Micro/nano Encapsulation via Electrified Coaxial Liquid Jets. Science. 295(5560): 1695-1698 DOI: https://doi.org/10.1126/science.1067595.

[24] Vajdai, A., B. Szabo, K. Suvegh, R. Zelko and G. Ujhelyi. 2012. Tracking of the Viability of Stenotrophomonas Maltophilia Bacteria Population in Polyvinylalcohol Nanofiber Webs by Positron Annihilation Lifetime Spectroscopy. International Journal of Pharmaceutics. 429(1-2): 135-137.

DOl: https://doi.org/10.1016/j.ijpharm.2012.03.018.

[25] Leung, V., and F. Ko. 2010. Biomedical Applications of Nanofibers. Polymers Advanced Techologies. 22(3): 350365.

DOI: https://doi.org/10.1002/pat.1813.

[26] Spasova, M., N. Manalova, M. Naydenov, J. Kuzmanova and I. Rashkov. 2010. Electrospun Biohybrid Materials for Plant Biocontrol Containing Chitosan and Trichoderma Viride Spores. Journal of Bioactive and Compatible Polymers. 26(1): 48-55. DOI: https://doi.org/10.1177\%2F0883911510391446.

[27] Reneker, D. H., A. L. Yarin, E. Zussman and H. XU. 2007. Electrospinning of Nanofibers from Polymer Solutions and Melts. Advances in Applied Mechanics. 4: 43 DOI: https://doi.org/10.1016/S0065-2156(07)41002-X

[28] Bellan, L. M., J. D. Cross, E. A. Strychalski, J. Moran-Mirabal and H. G. Craighhead. 2006. Individually Resolved DNA Molecules Stretched and Embedded in Electrospun Polymer Nanofibers. Nano Lett. 6(1 1): 2526-2530. DOl: https://doi.org/10.1021/nl061894.

[29] Greiner, A., J. H. Wendorff, A. L. Yarin and E. Zussman. 2006. Biohybrid Nanosystems with Polymer Nanofibers and Nanotubes. Appl Microbiol Biotechnol. 71 (4): 387-393. DOI: https://doi.org/10.1007/s00253-006-0356-z. Epub 2006 Jun 10.

[30] Yarin, A. L., E. Zussman, J. H. Wendorff and A. Greiner. 2007. Material Encapsulation and Transport in Core-shell Micro/Nanofibers, Polymer and Carbon Nanotubes and Micro/Nanochannels. Journal of Materials Chemistry. 75(25): 2585-2599.

DOI: https://doi.org/10.1039/B618508H

[31] Agarwal, S., J. H. Wendorff and A. Greiner. 2008. Use of Electrospinning Technique for Biomedical Applications. Polymer. 49(26): 5603-5621.

DOI: https://doi.org/10.1016/j.polymer.2008.09.014

[32] Dersch, R., M. Steinhart, U. Boudriat, A. Greiner and J. H. Wendorff. 2005. Nanoprocessing of Polymers: Applications in Medicine, Sensors, Catalysis, Photonics. Polymers Advanced Technologies. 16(2-3): 276-282. DOI : https://doi.org/10.1002/pat.568.

[33] Biazar, E. 2016. Application of Polymeric Nanofibers in Soft Tissues Regeneration. Polymers Advanced Technologies. 27(11): 1401-1540. DOl: https://doi.org/10.1002/pat.3820

[34] Thenmozhi, S., N. Dharmaraj, K. Kadirvelu and K. Hak Yong. 2017. Electrospun Nanofibers: New Generation Materials for Advanced Applications. Materials Science and Engineering: B. 217: 36-48. DOI: $\mathrm{http}: / / d x . d o i . o r g / 10.1016 \% 2 F j . m s e b .2017 .01 .001$

[35] Bhardwaj, N., and S. C. Kundu. 2010. Electrospinning: A Fascinating Fiber Fabrication Technique. Biotechnology Advances. 28(3): 325-347. DOI: https://doi.org/10.1016/j.biotechadv.2010.01.004.

[36] Rodoplu, D. and M. Mutlu. 2012. Effects of Electrospinning Setup and Process Parameters on Nanofibers Morphology Intended for the modification of Quartz Crystal Microbalance Surfaces. Journal of Engineered Fibers and Fabrics. 7(2): 118-123.
DOI: https://doi.org/10.1177\%2F155892501200700217.

[37] Datta, S., L. Rene Christena and Y. Rani Sriramulu Rajaram. 2012. Enzyme Immobilization: An Overview on Techniques and Support Materials. 3 Biotech. 3(1): 1-9. DOI: https://dx.doi.org/10.1007\%2Fs 13205-012-0071-7.

[38] Lima, J. d., F. N. Costa, M. A. Bastistella, P. Henrique and D. de Oliveira. 2019. Functionalized Kaolin as Support for Endoglucanase Immobilization. Bioprocess and Biosystems Engineering. 42(7): 1165-1173. DOI: https://doi.org/10.1007/s00449-019-02113-w.

[39] Abdolmaleki, A. Y., H. Zilouei, S.N. Khorasani and A. Abdolmaleki. 2017. Optimization and Characterization of Electrospun Chitosan/Poly (Vinyl Alcohol) Nanofibers as a Phenol Adsorbent via Response Surface Methodology. Polymers Advanced Technologies. 28(12): 1872-1878. DOI: https://doi.org/10.1002/pat.4075.

[40] Amna, T., M. Shamshi Hassan, D. Raj Pandeya, M. S. Khil and I. H. Hwang. 2013. Classy Non-wovens based on Animate L. Gasseri-Inanimate Poly(Vinyl Alcohol): Upstream Application in Food Engineering. Applied Microbiology and Biotechnology. 97: 4523-4531. DOI: https://doi.org/10.1007/s00253-012-4666-z.

[41] Yarin, A. L., E. Zussman, J. H. Wendorff and A. Greiner. 2007. Material Encapsulation and Transport in Core-shell Micro/Nanofibers, Polymer and Carbon Nanotubes and Micro/Nanochannels. Journal of Materials Chemistry. 17(25): 2585-2599

DOI: https://doi.org/10.1039/B618508.

[42] Schaechter, M. 2001. Escherichia coli and Salmonella 2000: the View from Here. Microbiology and Molecular Biology Reviews. 65(1): 119-30.

DOI: https://doi.org/10.1128/MMBR.65.1.119-130.2001

[43] Chong, E. J., T. T. Phan, I. J. Lim, Y. Z. Zhang and B. H. Bay. 2007. Evaluation of Electrospun PCL/gelatin Nanofibrous Scaffold Forwound Healing and Layered Dermal Reconstitution. Acta Biomaterialia. 3(3): 321-330. DOI: https://doi.org/10.1016/j.actbio.2007.01.002.

[44] Geng, X., O. H. Kwon and J. Jang. 2005. Electrospinning of Chitosan Dissolved in Concentrated Acetic Acid Solution. Biomaterials. 26(27): 5427-5432. DOI: https://doi.org/10.1016/j.biomaterials.2005.01.066.

[45] Pham, Q. P., U. Sharma and A. G. Mikos. 2006. Electrospinning of Polymeric Nanofibers for Tissue Engineering Applications: A Review. Tissue Engineering. 12(5): 1197-1211. DOI: https://doi.org/10.1089/ten.2006.12.1197.

[46] Baumgarten, P. 1971. Electrostatic Spinning of Acrylic Microfibers. Journal of Colloid and Interface Science. 36(1): 7179 DOl: https://doi.org/10.1016/0021-9797(71)90241-4.

[47] Stepanyan, R., A. Subbotin, L. Cuperus, P. Boonen and M. Dorschu. 2014. Fiber Diameter Control in Electrospinning. Appl. Phys. Lett. 105(17): 1-5. DOl: http://dx.doi.org/10.1063/1.4900778

[48] Keskin, N. O. S., A. Celebioglu, O. F. Sarioglu, T. Uyar and T. Tekinay. 2018. Encapsulation of Living Bacteria in Electrospun Cyclodextrin Ultrathin Fibers for Bioremediation of Heavy Metals and Reactive Dye from Wastewater. Colloids and Surfaces B: Biointerfaces. 161: 169-176. DOI: https://doi.org/10.1016/j.colsurfb.2017.10.047.

[49] Zhang, Y. Z., J. Venugopal, Z. M. Huang, C. T. Lim and S. Ramakrishna. 2006. Crosslinking of the Electrospun Gelatin Nanofiber. Polymer. 47: 2911-2917. DOI: https://doi:10.1016/j.polymer.2006.02.046

[50] Lee, S.-W., and A. M. Belcher. 2004. Virus-based Fabrication of Micro- and Nanofibers Using Electrospinning. Nano Letters. 4(3): 387-390. DOI: https://doi.org/10.1021/nl034911t.

[51] Larrondo, L., and R. ST. John Manley. 1981. Electrostatic Fiber Spinning from Polymer Melts. Journal of Polymer Science. 19(6): 933-940. DOI: https://doi.org/10.1002/pol.1981.180190603. 
[52] Megelski, S., J. S. Stephens, D. B. Chase and J. F. Rabolt. 2002. Micro- and Nanostructured Surface Morphology on Electrospun Polymer. Macromolecules. 35(22): 8456-8466. DOI: https://doi.org/10.1021/ma020444a.

[53] LuU, Y., K. Kim, B.S. Hsiao, B. Chu and M. Hadjiargyrou. 2003. Development of a Nanostructured DNA Delivery Scaffold via Electrospinning of PLGA and PLA-PEG Block Copolymers. Journal of Controlled Release. 89(2): 341-353. DOI: https://doi.org/10.1016/s0168-3659(03)00097-x.

[54] Haider, A., S. Haider and I. K. Kang. 2018. A Comprehensive Review Summarizing the Effect. Arabian Journal of Chemistry. 11 (8): 1165-1188.

DOI: https://doi.org/10.1016/j.arabjc.2015.11.015.

[55] Huang, L., K. Nagapudi, R. P. Apkarian and E. L. Chaikof. 2001. Engineered Collagen-PEO Nanofibers and Fabrics. Journal of Biomaterials science: Polymer Edition. 12(9): 979-993. DOI: https://doi.org/10.1163/156856201753252516.

[56] Lee, S.-W., and A. M. Belcher. 2004. Virus-based Fabrication of Micro- and Nanofibers Using Electrospinning. Nano Letters. 4(3): 387-390. DOI: https://doi.org/10.1021/nl034911t.
[57] Haghi, A., and M. Akbari. 2007. Trends in Electrospinning of Natural Nanofibers. Physica Status Solidi (a) - Applications and Materials Science. 204(6): 1830-1834. DOI: https://doi.org/10.1002/pssa.200675301.

[58] Tan, S.-H., R. Inai, M. Kotaki and S. Ramakrishna. 2005 Systematic Parameter Study for Ultra-fine Fiber Fabrication via Electrospinning Process. Polymer. 46(16): 6128-6134. DOI: https://doi.org/10.1016/j.polymer.2005.05.068.

[59] Gupta, P., C. Elkins, T. E. Long and G. L. Wilkes. 2005. Electrospinning of Linear Homopolymers of Poly(methyl methacrylate). Polymer. 46(13): 4799-4810. DOI: https://doi.org/10.1016/j.polymer.2005.04.021.

[60] Li, D. and Y. Xia. 2004. Electrospinning of Nanofibers: Reinventing the Wheel. Advanced Materials. 16(14): 11511170. DOI: https://doi.org/10.1002/adma.200400719.

[61] Wang, X., C. Drew, S. H. Lee, K. J. Senecal, J. Kumar and L. A. Samuelson. 2002. Electrospun Nanofibrous Membranes for Highly Sensitive Optical Sensors. Nano Letters. 2(11): 1273-1275.

DOI: https://doi.org/10.1021/nl020216u. 
